\title{
Emerging Apprenticeship Practitioner Roles in England: Conceptualising the Subaltern Educator
}

\section{Bill Esmond ${ }^{1}$ (D)}

Received: 22 August 2018 / Accepted: 24 September 2019/Published online: 26 October 2019

(C) The Author(s) 2019

\begin{abstract}
TVET educator roles and identities vary internationally, and are subject to repositioning, for example as the relative significance of institutions and the workplace change within national systems. In English apprenticeships, a key position has long been occupied by competence assessors, whose non-teaching role has related uneasily to those of professional educators. Following the introduction of new apprenticeship standards, former assessors are increasingly being allocated training responsibilities, raising issues about the expertise, identities and professional formation both of these emerging practitioners and of vocational educators in general. A qualitative study of assessors who have assumed greater training responsibilities examined these issues through individual and small-group interviews. Participant accounts of diverse and contested practices and environments suggested a need to conceptualise their roles in ways that draw upon but go beyond accounts of professionalism and occupational expertise developed at earlier stages. Drawing on Gramsci, the concept of the subaltern educator is put forward to characterise the complex position of these staff in the current climate of further education, the need for enhanced, rather than diminished, professional formation and wider possibilities for professional enhancement at a time of uncertainty for all vocational educators.
\end{abstract}

Keywords Apprenticeship · Assessors · Professionalism · Workplace learning · Teacher education · Competence

\section{Introduction}

The roles of staff in technical and vocational education and training (TVET) vary across jurisdictions, as well as changing when these systems alter. Distinctive classroom teacher and workplace trainer roles are widely recognised (OECD 2013; ET 2020

Bill Esmond

W.esmond@derby.ac.uk

1 Institute of Education, University of Derby, Kedleston Road, Derby DE22 1GB, UK 
Working Group on Vocational Education and Training 2018; Billett 2011); but the significance of these and of other, intermediate, roles is subject to change, for example when teachers are called on to adapt to employer requirements, or workplace trainers to demonstrate higher quality (Ertl and Sloane 2004; Hemkes and Schemme 2013). An important trigger for change has been the growth of workplace learning at the expense of school based TVET, leading to questions of the relationships between, and the relative importance of, teaching and learning in work and classroom settings (Tanggaard 2007). Such changes to vocational educator roles have provided opportunities to re-examine educators' practices, identities and source of expertise, including their professional formation.

An example of such changes is furnished by apprenticeship 'assessors' in England who formerly occupied what were generally considered non-teaching roles. Their work formerly centred on assessment for the National Vocational Qualifications (NVQs) used to certify most apprenticeships in England since 1994 (QCA 2002): a form of 'competency-based education and training' (CBET) designed to 'decouple assessment from education and training' (Winch 2000, 88). The assessor role did not, consequently, formally entail teaching or training apprentices; but it did enable colleges and training organisations to provide external assessment services to firms. Competence assessors came to constitute a distinctive and sizeable part of the further education (FE) workforce, particularly amongst independent training providers (ITPs): a Work Based Learning Workforce Survey (2014) described a third of the ITP workforce in $2012 / 13$ as assessors.

Now, following reforms based on the Richard Review of apprenticeships (Richard 2012), assessors are increasingly moving into teaching or training activities. Now ambivalent new job titles appear in recruitment advertisements: 'assessor-coach', 'assessor-trainer' or (like 29\% of ITP staff in a 2016-17 survey), 'learner-facing technical staff' (Frontier Economics 2018). These changes have significance beyond assessor staff, in the way that Robson and Bailey (2009) explained how the labour of 'associate professionals' can have implications for established teaching professionals. Despite differences in rewards and status, distinctions among assessors, trainers and teachers were never absolute: many assessors also taught in FE colleges, or were workplace trainers; whilst tens of thousands of teachers and workplace trainers also studied for assessor qualifications, because of the way that competency-based assessment shaped practice in 'realistic work environments' in colleges, and even classroom teaching, dominating vocational learning in England (Brockmann et al. 2008). The examining body City \& Guilds, with around $35 \%$ of registrations, reports that 13,723 candidates completed full-length assessor qualifications over the last decade, implying some 40,000 candidates across the sector, whilst other assessors held older valid qualifications (City and Guilds 2019). Whilst assessors are seldom co-located with classroom teachers, changes to their role have significance for vocational educators in established teaching or training roles.

The significance of these changes requires that they be located within the long-term discussion of vocational educator professionalism that has taken place particularly in England. The imposition of new expectations as part of a neo-liberal performativity, whilst educators aspire to develop their own values and approaches to professionality, has been the source of long-term contestation in the sector and across public services (James and Biesta 2007; Gleeson et al. 2005). Demands for increased flexibility and 
closer engagement with the workplace have been associated with discourses reframing professionalism as both educationally and occupationally based (Hodgson and Spours 2013; ETF 2014; Esmond and Wood 2017). At such moments of change, it is also important to note possibilities as well as challenges: Avis (1999) drew out the potential inherent in changes to educational practice even as neo-liberal regulation was strengthening its hold. Nevertheless, these changes are taking place now in a significantly weakened further education sector whose resources and limited autonomy have been further eroded.

This paper draws on a qualitative study of apprenticeship assessors taking on new training responsibilities during the implementation of apprenticeship 'standards'. Its point of departure was how professional development might support transitions into these roles. Its initial concerns were descriptive and qualitative: how widely had the post-Richards changes been implemented across their vocational areas and how had this affected their professional practice? What were the current issues in respondents' industries and vocational areas? The data, however, placed participants' practice in a web of relationships extending beyond these relatively narrow questions. It required the examination of the whole relationship between educators and their workplace, and of the wider questions of what it means to be a vocational education professional.

The following section explains first the recent apprenticeship reforms in England, including background discussion of how competency-based apprenticeship came to provide a key setting for assessor activity, and how the reforms are changing educator roles. The next section draws on theorisation of changing vocational roles during the last 20 years, including both those of teaching and non-teaching staff. The interpretive methodology and qualitative methods of the empirical study are described next, before key findings of the study, organised around four dimensions of the data, are set out. The following section analyses the findings in the light of earlier theorisation of vocational educator roles, indicating three patterns of response to the changes. This leads to a proposed descriptive characterisation of the subaltern status of these educators, and to suggestions of how this conceptualisation can contribute to the future development of work-based and other vocational educators.

\section{Apprenticeship in England: Changing Models and Practices}

The Richard Review of apprenticeships (Richard 2012) proposed to disrupt a framework that has shaped most apprenticeships in England for 25 years. Whilst all apprentices in England have trained for an identified occupation whilst working for an employer, only the larger firms have provided their own apprentice training and assessment. Instead, most apprenticeships have been facilitated by 'provider' training organisations which have contracted with employers to provide assessment, certification and other administrative requirements, often including furnishing the apprentice: the Association of Employment and Learning Providers (AELP) claims that its 900 members (mostly ITPs) 'support employers in the delivery of over $75 \%$ of apprenticeships in England' (AELP 2019). Larger firms also contract with colleges or ITPs where they lack the expertise to manage successive funding and quality regimes, leading Fuller and Unwin (2009) to suggest that the state had effectively become the employer. Such arrangements have their origins in the (initially 'modern') apprenticeships introduced in 1994, which little resembled 
traditional employment-based apprenticeships or their international equivalents (Ryan and Unwin 2001), with the UK government funding and directing a quasimarket within which training providers offer services to employers (Hodgson et al. 2017). Through a combination of government measures to convert earlier schemes (notably Train to Gain, mainly for adults) into apprenticeships, and financial incentives for employers, numbers under Conservative-led governments reached around half a million starts per year between 2011/12 and 2016/17 (Keep and James 2011; Powell and Phelan 2019). This growth was not always matched by an increase in quality: the regulator Ofsted noted that 'low-value' apprenticeship courses entailed the accreditation of existing competences, with 'often... too little training whilst at work or during off-the-job learning sessions' (Ofsted (Office for Standards in Education). 2015, p.7) and in an annual report that one in five apprentices was trained by an 'inadequate' provider (Ofsted 2017).

The professional working most directly with the apprentice under this model was the NVQ assessor. Conceptually, the assessor is neither teacher nor trainer: the CBET discourse of 'provision' and 'delivery' is unconcerned with 'educator' roles but aims to accredit workforce skills through judgments based on observation, or discussion, rather than written tests. Assessors are expected to provide detailed records of how their decisions have been made, based on a philosophical premise that practical knowledge could be assessed in this way (Jessup 1991; Wolf 1995). In addition to demonstrating their 'occupational competence', assessors have completed qualifications quite distinct from those preparing teachers. Although the titles of the awards have changed several times since 1994, their subject matter has remained confined to assessment processes and their management (Day 1996; Ollin and Tucker 2008, 2016).

The Richard Review (Richard 2012) expressed an intention to disrupt the training quasi-market by strengthening the employer's role: '...teaching and training their staff, not simply seeing this as a task for the Government or training providers' (106), with 'no unnecessary process and prescription for how an apprentice reaches the desired outcome' (82). The key change ushered in by the Review was the replacement of the qualification-based frameworks that had added knowledge-based 'technical certificates' and generic elements to the work-based NVQ (Boreham 2002). Instead, apprenticeship 'standards' based on two-page summaries are now created by 'employer-led' 'trailblazer groups' and approved by a government-appointed Institute of Apprenticeships (DBIS 2013; Newton et al. 2015). In the most significant change for assessors, NVQs were to be replaced by end-point assessment (EPA): the critical judgments on an apprentice's progress would now be made at the end of the course (Richard 2012, p.4; Ofqual 2017). From this point on, funding became available only for training provided off-the-job, which should take $20 \%$ of the apprentice's time, and for end-point assessment (HM Government 2019).

These changes left the training market largely intact whilst a levy on larger employers and the $20 \%$ requirement provided stronger incentives for training to assume greater importance in apprenticeships. Providers began to develop new offers of training that would prepare apprentices for the end-test, with assessors assuming roles that included workplace training. Since many of the new 'standards' excluded qualifications, particularly at lower levels, workplace training could now displace college-based study entirely in some areas, leaving the assessor in sole charge of the apprentice's education and training. Against this background, assessors 
are emerging as the most appropriate 'resource' to provide such training. How, then, might their development as educators take place? Insights from earlier studies in related areas are explored in the following section.

\section{Vocational Educators, Professionality and Change}

Issues of identity and professional autonomy have been contested in the English further education sector for over 20 years. Important contributions responded to a 'reprofessionalisation' when the New Labour government made teacher-training compulsory in 2007, alongside membership of a professional body for teachers, the Institute for Learning. Much debate at that time revolved around distinctions between the managerialist, imposed professionalism associated with new public management and the performative reshaping of the public sector in response to neoliberalism, and democratic alternatives emerging among practitioners (Gleeson et al. 2005). The most extensive study of the FE sector and its 'learning cultures' identified common aspirations for a professionalism attentive to students and subject expertise independent of any shared political ideas (James and Biesta 2007). Contrasting accounts of professionalism 'as subject to external rules and constraints' to those of 'agents with power to define their own conditions of work', Gleeson and James $(2007,452)$ sought to discover not how these might be reconciled but how they were mediated, including through practices at college level. Pointing to the 'ambiguities and tensions, the disruptions and contradictions of lived professional experience', they drew attention both to 'creative and restrictive dimensions' called forth by marketisation and managerialism (459). Such ambiguities also emerged from Avis's (1999) analysis of the way attempts to reorganise professional identity and destabilise opposition to change 'serve both to open up and close all forms of professional identity' (247). An interest in effective pedagogy and efforts to establish a research culture were seen to 'open up a space for teachers to seize and utilise to develop new forms of expertise', whilst 'these possibilities are constrained by the discursive context and forms of surveillance in which they are placed' (260). Within the context of a performative and regulatory professionalism, then, these writers identified possibilities for more progressive practice even within neoliberal constraints.

Against these thoughtful accounts must be set the increasingly problematic position of many apprenticeship staff. Assessors and even workplace trainers are discursively located outside the role of teacher, which continues to provide a source of identity and coherence, notwithstanding important questions of professional formation and insecure employment (Avis and Orr 2014). By contrast, teaching standards formerly placed assessors in the marginal category of 'teacher-related roles' (Lifelong Learning 2007, p. iii). Conversely, assessors already report filling gaps for deficient training in supposedly assessment-only roles (James and Diment 2003; Armstrong 2007, p. 9). The 'flexibility' of staff in non-teaching roles has long provided questionable benefits for educators and learners alike. Robson and Bailey (2009) drew attention to the way LSWs were differently positioned from teachers in relation to these discourses, ascribed a more direct 'caring' role whilst teachers assumed a more authoritative, masculinised role. Whilst teachers were constructed as 'authentic' professionals, LSWs became 'distanced from the values of objectivity and authority that underpin a traditional discourse of professionalism' as they appeared to build relationships with learners (112). Since this 
time a range of para-professional roles has been created across colleges, with vocational coaches, demonstrators and technical experts with various titles assuming support roles in workshops and other settings, displacing teachers but without visible benefits (Esmond and Wood 2017). Alongside the terminology of 'providing' and 'delivery', such uncertain descriptions as apprenticeship 'staff' and 'practitioners' also evade questions of educational content. Learning at work too often calls up narrow definitions, opposing workplace practice to classroom-based theory, skills to knowledge, or training to education.

Narrow conceptualisations of training appear sustained by 'apprenticeship' schemes that accredit the prior knowledge of the workforce (Fuller and Unwin 2017). 38.2\% of apprentices in 2016/17 had been employed for over 12 months before starting their apprenticeship (DfE 2019, 12). Concepts such as mimesis (Billett 2014; Chan 2015) and incidental learning (Marsick and Watkins 1990) centre on the autonomous learner and their relationship with experienced workers. Fuller and Unwin's (2003, 2004) models of 'expansive' workplace learning mention favourably 'managers as facilitators of workforce and individual development' $(2004,130)$ rather than high-status trainers. The contributions of trainers can prove ephemeral even in countries where workplace learning is more effectively integrated within TVET (Nägele and Neuenschwander 2016), especially in apprenticeships, which centre on learning from experienced workers (Fjellström 2017). Winch (2000) argued that narrow definitions had been used to describe training as simply the process of cognition: more complex understandings would include a gradual acquisition of expertise, the interpenetration of knowledge and skills, an ability to apply them to fresh situations and a relationship with foundational knowledge. Beyond training, wider work-based teaching and learning activities are determined by 'characteristics of work and work environments [which] vary enormously and have done so historically' $(2000,84)$. This makes it difficult to define what the vocational educator's work should be across all occupations; and indeed the role of work-based staff and college-based professionals could usefully extend to helping apprentices explore connections between industry problems, broader examples of industry practice and their theoretical generalisation (Guile and Young 2003). These earlier elaborations set out in broad terms the possibilities that exist around vocational educator roles. How far these are attained among former assessors is examined in the following sections.

\section{Methodology and Methods}

The data examined here were collected at the end of a series of short courses supporting the development of teaching practices among assessors moving into training roles. A government promise of 'support to ensure teachers' knowledge and skills reflect up-todate occupational standards' (HM Government 2015, p.45) had materialised as the 'Future Apprenticeships' programme, a range of training activities largely directed at former assessors, organised through the body leading professional development in the sector (Education and Training Foundation 2016). Within this programme, a course designed to provide teaching skills to assessor staff was trialled, evaluated and redesigned during 2017 and 2018 in a project led by the researcher's institution. This 
course had been written by a leading practitioner from another institution and taught, using this leading practitioner's materials, with local modifications, by apprenticeship staff from the six centres hosting the programme. These were all FE colleges with significant apprenticeship provision: the colleges selected the candidates for the course, based on their perceptions of a need to update staff skills, and provided the course tutors from among their own apprenticeship staff and teacher-trainers. The researcher, who had organised the programme evaluation, conducted an additional qualitative study among apprenticeship staff completing the second phase of the course, exploring the current experience of apprenticeship practitioners and its implications for their future practices, status and identities.

The sample of for the study was therefore a 'convenience sample' $(n=16)$, not intended to represent the full range of apprenticeship assessors. All participants worked for FECs and none for private providers (ITPs); half had completed a teacher-training programme, albeit usually at the start of their education career and in some cases over 20 years earlier (see Table 1). However, the sample was purposefully recruited among these groups: because patterns of workplace learning were known to vary across industries, recruitment aimed to ensure that different subject areas were represented, alongside different lengths of time working on apprenticeships, and the interviews were grouped on this basis. A total of 8 individual and small-group interviews took place. The data collected on this basis are not claimed to provide a comprehensive picture of apprenticeship practice in England; but they illustrate the experiences of education staff whose voices are seldom heard in the literature, at a critical moment of change. An anonymised list of participants is given below:

Table 1 Participant anonymised names and key characteristics

\begin{tabular}{llllll}
\hline 'Name' & Subject area & Gender/ethnicity & $\begin{array}{l}\text { Years' work in } \\
\text { apprenticeships }\end{array}$ & $\begin{array}{l}\text { ITE } \\
\text { trained }\end{array}$ & Interview No. \\
\hline Lorna & Hairdressing & Female white & 15 & $\mathrm{Y}$ & 1 \\
Sandra & Beauty therapy & Female white & 9 & $\mathrm{Y}$ & 1 \\
Hayley & Catering & Female white & 11 & $\mathrm{Y}$ & 1 \\
Carl & Brickwork & Male white & 13 & $\mathrm{Y}$ & 2 \\
Hassan & Accounts & Male Asian & 23 & $\mathrm{Y}$ & 3 \\
Ali & Accounts & Male Asian & $<1$ & $\mathrm{~N}$ & 3 \\
Kimberly & Business admin & Female white & 4 & $\mathrm{~N}$ & 3 \\
Sheila & IT & Female white & 18 & $\mathrm{~N}$ & 4 \\
Simon & Engineering & Male white & 2 & $\mathrm{~N}$ & 5 \\
Dennis & Engineering & Male white & 2 & $\mathrm{~N}$ & 5 \\
Donna & Engineering & Female white & $<1$ & $\mathrm{~N}$ & 6 \\
Christine & Early years/education & Female white & 7 & $\mathrm{Y}$ & 7 \\
Charlotte & Early years/education & Female white & $<1$ & $\mathrm{Y}$ & 7 \\
Brian & Management & Male white & 15 & $\mathrm{~N}$ & 8 \\
Jeanette & Management/Health \& & Female white & 25 & $\mathrm{Y}$ & 8 \\
Angela & Social Care & & 5 & $\mathrm{~N}$ & 8 \\
\hline
\end{tabular}


Ethical issues were an important aspect of the research design, which was approved by university ethical review, rigorously considering possibilities for harm to participants. Care was taken to avoid the inclusion of any identifiers: individuals were anonymised at the point of data collection and pseudonyms are used throughout the paper. The interview data was not shared with employer organisations or the funding body for the project, whose status is partly sector-based and partly government-funded. The positionality of the researcher is significant for the validity of the study. Although the evaluation project described above was organised by the researcher's institution, and the researcher also organised other aspects of evaluation, the course authorship, teaching and assessment of participants' coursework were carried out independently, so that participants would have no perception of the researcher as holding any position of authority. The interviews reported here were held separately from the taught sessions and course evaluation: the distinction between these activities and the research interviews was made explicit in participant briefings, which also made clear the rights of participants to withdraw during or after interviews.

The primary purpose of the study was to understand how the world of the assessorturned-trainer was taking shape, how educator identities were emerging and what this implied for the professional formation of these staff. The study built on a lengthy tradition of interpretive exploration of identity change in response to shifting organisational context (Strauss 1997), using the qualitative methods of semistructured individual and small-group interview. These semi-structured interviews took place over around an hour with individuals, whilst longer interviews brought together small groups of two or three participants on an industry basis. The interviews followed a guide identifying key themes, based on apprenticeship policy discourses and literature on teacher professionalism. Thus, opening questions addressed the type (for example industry, occupation, level, framework or standard) of apprenticeship that participants facilitated through their work. Later questions addressed course requirements and specific practices. A further category of questions discussed how apprenticeship training was coming to be organised, including policies and practices for off-the-job training, as well as the facilities and employer relationships affecting this area. Throughout the interviews, the intention was to discover the effects of recent or expected changes on teacher and trainer identities. In all aspects, the data collection was designed to represent the views of participants accurately, drawing on Seale's (1999) proposals for 'low-inference' methods. For example, interviews were taped, transcribed verbatim in full, with the transcripts then reviewed against the original recordings to reduce the risk of misinterpretation, and carefully coded using both preidentified codes and others that emerged during analysis.

After data collection and transcription, analysis moved through coding to thematic analysis. Transcripts were coded according to an initial scheme developed using concepts from the literature and included in the interview guide. However, the data produced additional categories: how participants distinguished between teaching and other educator roles and percieved distinctions between firm-based and industry-based expertise. Thematic analysis of the coded data then sought to identify a smaller number of central themes in the tradition of grounded theory (Corbin and Strauss 2015). The intention here was to capture the way that participants rationalised their emerging practice, rather than to capture through observation and objectively characterise this practice: whatever its limitations, this 'naturalistic' approach (Silverman 2014) 
addresses directly the question of how staff view their emerging identities. During the coding, additional categories and degrees of difference emerged, which were closely examined in the light of Delamont's (1992) call for attention to contrasts and irregularities, as well as themes, patterns and regularities. The findings are addressed below.

\section{Findings}

The key significant findings, then can be set out under four major themes: the extent to which respondents' practice had changed, as the introduction of apprenticeship standards had impelled them into training roles; the comparisons they made between their emerging roles and those of established educators, particularly classroom-based teachers; contestation between educational practice and production imperatives; and the changing content of the apprenticeship curriculum mediated by their practice.

\section{A Training Transformation?}

Responses to questions about the extent of changes to practice varied significantly. For education and childhood (E\&C) staff, new practices were identified as more developmental than earlier competence assessment norms; but others saw less of a distinction between their earlier assessor practice and their experiences of classroom teaching. The characterisation of earlier assessor work offered by Christine reflected widespread criticisms of that role:

Years ago, it was just like, 'Can you do that criteria?' And then tick it off and sign it off - and there's your qualification. ... People are saying it's a teaching role, and it is, really; but we've never been seen like that before (Christine, E\&C).

Practices more recognisable as teaching may be more attractive in an area focused on educational practices, with strong placement and mentoring traditions: a second E\&C respondent, new to apprenticeship work, enumerated the practices she intended to bring from her former primary teaching experiences:

I will be differentiating, I will be stretching, I will be questioning, I will be challenging, I will be planning, making sure I am meeting the needs of learners. It's all that, all those teaching skills that you're taught. (Charlotte, E\&C).

Yet other staff, with longstanding teaching and assessing experiences, saw less of a distinction. They reported earlier training as part of the assessor role and suggested that little was changing, particularly in more practice-based fields such as personal services. Lorna summarised three activities for work-based staff:

One is the final assessment and you're examining, for want of a better word. There is the correction area, where you are watching somebody work: and they are not really up to standard and you are trying to suggest ways in which that could be improved ... And then there's the off-the-job training where you have got them either in college or in an area away from the actual shop floor where you 
are actually showing them how to do something. There will always be these three areas and it is never going to go away. (Lorna, hairdressing).

These categories do not quite match those prescribed by assessment practice. The first is the designated role of an NVQ assessor, the second describes formative feedback and the third demonstration-based but formal teaching. This area theoretically lies outside assessor expertise, across the 'fault line' identified by James and Diment (2003, p.414). The longstanding 'hidden' training practice problematises the notion that the apprenticeship standards are introducing new training roles. This ambiguity was even expressed in $\mathrm{E} \& \mathrm{C}$ :

It also adds uncertainty about how far these practices can be described as teaching. These distinctions among educator roles were elaborated by participants who differentiated between their former roles and the challenges associated with teaching.

\section{Differentiating Educator Roles}

Many of the distinctions between assessor practices and those associated more widely with teaching related less to classroom practice than to planning, preparation, and reflection:

There's much more planning as well as much more resources involved now. And I think that the high caseloads that we've had previously as assessors will have to be dropped in order to take into account the time for planning, teaching and learning and reflection that we've never had (Angela, business).

I've spent a lot of development time developing the course ... looking at the resources and what we need to do ... so that we deliver a quality process (Brian, management).

For these respondents, the new roles were associated less with classroom-based autonomy than with organisational and performative pressures. Others pointed to performative pressures:

I am worried about them pointing the finger at me not having done my job properly because they haven't passed it... I am worrying they will turn around and say, 'Well, why hasn't she gone through? What have you not done?' (Sandra, beauty therapy).

Significantly, participants based in engineering, where theoretical aspects of the subject were still taught in college settings, distinguished their emerging training roles from those of classroom teachers by the content of the curriculum. With technical content still taught in classrooms, work-based engineering staff focused on behavioural requirements.

They will be doing the basic training on the machinery in college with the fulltime [teaching] staff, so quite a lot of the training that we will probably do with them when we're out in company will be around behaviours... and their own personal progression and development to become the craftsman that ... we want 
to be... That's the way it has always been: you've always had an external assessor for work-based learning and then you've had your college lecturers that do the college side of things, the technical side of things. (Simon, engineering).

The high level of learning still based in colleges appeared to make it difficult to reach the $20 \%$ off-the-job training required by apprenticeship standards:

Any training you get in a company it's 'Get it recorded!' ... They get quite a lot of it early on and then it might thin down a bit; and then every now and then it might be, 'Right, you got to run a training course for that machine, record that,' (Simon, engineering).

A further differentiation was the acknowledgement of work-based mentors, 'a really, really important link' (Simon, engineering). These roles were not mentioned in more practice-based fields, where apprentices work more directly with small employers or self-employed practitioners. Such differences also applied to negotiating these varying relationships with employers.

\section{Contesting the Learning Environment}

Respondents from all industries acknowledged the need to negotiate spaces for training in or around locations designed for production. However, in education, participants worked within traditions of supporting new entrants; whilst in engineering 'a canteen or an office somewhere at the side' (Dennis, engineering) was to be expected. But in the confined spaces of service-industry settings, learning environments often competed with production needs:

I am normally sat in a restaurant, so you have got your background music and other distractions going on. And sometimes people come and interrupt saying, 'Excuse me but can so and so just... go and do this?' ... And I don't see it's going to alter massively, we've got employers who don't want to release people and they don't have training rooms as such, do they? (Hayley, catering).

Sheila, an IT assessor, identified similar problems but used technology to minimise them:

It's a small office and everybody can hear everything and I'm sat on a chair behind a door, you know if somebody comes in the door ... but that's just down to space really. Most employers are accommodating, but again I use technology and I send meeting requests through Outlook: I never turn up without anybody knowing, everybody knows when it's happening and how it's happening (Sheila, IT).

Such precautions do not guarantee a suitable learning environment but are important activities for work-based staff, which classroom teachers rarely experience. They are not matters of physical space alone: apprenticeship is predicated on the workplace's opportunities to learn, or to practice methods learnt in school or college. In beauty therapy, despite a well-established tradition of work-based learning, these might not materialise: 
I might come in or on a review it will come out that, 'I haven't done any manicures at work because she is teaching me acrylic nails.' Because that is bringing in more money, which is at a different level at the minute to manicure and pedicure. (Sandra, beauty therapy).

Such difficulties could vary according to the level of study. Jeanette compared her different experiences on apprenticeships in health and social care (H\&SC) to those on higher-level management apprenticeships:

The employers are engaged: and they are giving them time and a room and that kind of thing. But [in] health and social care that's been a massive problem, giving them time. There's a lot of them haven't been given the twenty percent, and it's just a case of 'Well, we need you, we're short staffed, this, that and the other. We can't give you that time.' So it's been a bit of a battle. (Jeanette, $\mathrm{H} \& \mathrm{SC})$.

Donna, teaching higher-level engineering standards, reported easier access, just as for Brian, teaching management, the standards were 'essentially good', needing only 'continuous improvement'. However, for care apprentices, work pressures provided greater difficulty:

... They're not allowed to have their phones, they're not allowed to have access to the internet in the homes, so it's been a huge problem for them and they're going home and doing all the work on the weekends ... And the twenty percent, oh, you've had to be very creative... any time that they spend with other health professionals, nurses coming to homes, doctors, anyone like that, anytime that they spend with them, they might be dressing a wound but 'They're learning about it' (Jeanette, H\&SC).

These differences based on workplace hierarchies had consequences for accounting apprentices. Students in entry-level jobs have in the past been able to progress rapidly to professional levels of study. But without promotion, a lack of opportunities to practise more advanced skills could limit their progression to level 3 or above:

They're thinking, 'Our employee is doing accounts, why does she or she need to be looking at this? Why do they need to be looking at implications for this sector or that sector or the commercial side of the business, why do they need to do that? This is where we're then going to have to step in and say 'Right, this is the importance of it,' (Hassan, accountancy).

Whilst Hassan described what appeared to him to be local problems, these hierarchical issues flowed directly from the standards 'linking their learning with their practical job description' (Ali, accountancy). The training provided by standards appeared to be limiting the scope of apprenticeship to local practice, raising a further area of tension, between the knowledge requirements of firms and broader industry knowledge. 


\section{Firm-Based and Industry Training}

This fourth area reflected a relatively narrow scope of learning long remarked in English apprenticeships. Apprenticeship standards have developed a far higher level of differentiation than earlier generic qualifications offered, with approaching 1500 standards expected, compared to the 2-300 apprenticeship routes available in Austria, Germany or Switzerland (Kuczera and Field 2018). Consequently, apprentices may be less able to access generalised industry knowledge. Carl in construction described how opportunities for apprentices to meet qualification requirements had become difficult because of the industry's greater division of labour. Small firms could not offer opportunities to practise some skills:

Most gangs now only do the super structure, from DPC [damp-proof course] up to wall plate and the gables, whereas included in the qualifications is a setting out unit. Now the setting out is mainly done now by the groundwork companies, so we're then having to get the apprentice to go with the gang other than the one they work with to gain experience in setting out (Carl, brickwork).

Carl expected the standards to overcome this difficulty through greater specialisation, effectively through a narrowing of the knowledge offered by more specialised apprenticeships This is emerging as a key problem for English apprenticeship. In a service-based small business, the owner may be the sole arbiter of expertise, whilst in larger firms, knowledge, although more widely distributed, may take a narrow form in an 'employerdriven' curriculum. Whilst vocational educators might provide broader expertise, few participants in this study had developed the confidence to advance such claims:

Always a dodgy one when you are working in somebody else's business because you will find that person has already been shown to do it that way, often by the owner of the business. And you are coming in and saying, 'Have you tried this? And have you tried that?' So, you have to be very careful about the way that you word those things (Lorna, hairdressing).

That such levels of autonomy appeared to lie beyond the practice of many emerging trainers constitutes a key difficulty for their roles.

\section{Analysis}

In reporting their experiences within the landscape emerging from the Richard Review, respondents identified new opportunities and challenges, as well as continuities. Their varying responses, sometimes contrasting and at others overlapping, identified new possibilities for developing their professionality, rationalised their existing practice, noted the mounting challenges of facilitating learning at work, or accepted relatively marginal roles. To some extent, different responses reflected the varying practices, knowledge bases and traditions of the industries and vocational areas in which they worked. However, they also represented the different extents to which practitioners felt able to justify their existing expertise and how far they could imagine transitions into 
more educational roles: the broader conceptualisations of training envisaged by Winch (2000), or engagement with boundary-crossing and teaching practices beyond the confines of industry training.

As Avis (1999) suggested, spaces in which genuinely educational aspirations and practices can emerge and thrive may be created even within a neoliberal reshaping of vocational education. The emergence of such aspirations is evidenced by the data. For example, whilst workplace knowledge is generally represented in policy discourse as the possession of employers, participants demonstrated an awareness of how an external educator can provide a broader view of industry-wide knowledge than is furnished by the practice of an individual workplace. Nor did the difficulties posed by many work environments prevent participants from developing practices that enable them to interact effectively with apprentices. Rather than seeing the workplace as an inferior setting where the 'authentic' professionalism of the classroom cannot be attained, the data can be seen as indicative of the possibilities of different types of professionalism, exploring different pedagogies and practices.

Nevertheless, it is important to recognise current difficulties. Whilst many assessors aspire to develop their teaching practice, and to build on earlier formal and informal teaching experiences and development activities, such transitions operate with difficulty in environments dominated by production pressures and beyond this by the requirements of the training market. Policy discourses that promote 'the skills employers want' whilst limiting the aims of learning to local contextualised skills serve to confine the space for contesting notions of professionality.

The data is of course framed by the policy landscape, institutional and workplace settings within which they are formed. A decade ago, Gleeson and James (2007) reported the conflicted professionalism of tutors who had developed dispositions 'generated in different, prior circumstances' (461) but mediated by current managerialist pressures: they contrasted this with new practitioners on 'assessment only' contracts 'occupy[ing] a more constrained, contractually-defined relationship with the learners' (ibid.). Whilst the institutional pressures and technologies of performativity within institutions figured little in this data, workplace practice provided its own constraints and relationships. Following a decade of austerity, the space in the English 'skills sector' for a professionalism that includes 'strong commitments to teaching, to fostering student learning... and to self-development or learning as a professional' (Gleeson and James 2007, 456) has narrowed considerably. The position of associate or paraprofessionals, as discussed by Robson and Bailey (2009), lacks even the secure identities identified by Avis and Orr (2014). In the workplace, the data has demonstrated further obstacles to developing alternative approaches to professionality. On the basis of this analysis, the final section suggests possibilities to move on to an alternative conceptualisation.

\section{Conclusion: Professionalism and the Subaltern Educator}

For much of the last two-and-a-half decades, the practice of vocational educatiors and associate professionals has been analysed through the propositions of competing professionalisms. An alternative conceptualisation would describe the apprenticeship practitioner on the basis of the aspirations and limited resources for development that 
the participants in this study variously demonstrated. Their marginalised position, uncertain identities and struggles to create practicable learning environments recall Gramsci's use of the term 'subaltern' for dominated social groups, including the rural poor of the Italian south and islands, who were less directly involved in the main political struggles of Italian history. Neglected by the main progressive forces in Italy during the nineteenth-century Risorgimento leading to unification, and class struggles of the early twentieth century, the rural poor often provided forces for reaction (Gramsci 1992, pp. 136-151). However, the use of this terminology is also consistent with a commitment to articulating hidden struggles and representing accurately the motives and aspirations of their participants (Guha 1988). Apprenticeship staff in England have also suffered neglect and marginalisation, and if neglected by those seeking to bring about more just and broadly-based educational practices, could conceivably become the means by which narrow curricula and pedagogies might be strengthened rather than diminished in workplace-only training. Correspondingly, it is no less important to recognise their potential to bring fresh resources, wider knowledge and new approaches to apprenticeship practice. Realising the potential of apprenticeship educators requires that educators and researchers accurately capture their current position, as well as recognising its potential and its pitfalls.

The possible evolution of the assessor role towards a more coherent educational practice has originated with the apprenticeship standards and their emergence can also be linked to an international imperative to recruit occupational specialists into vocational teaching. This can provide a rationale for the diminution of professional formation rather than any serious endeavour to extend 'subject' expertise into teaching practice. International advocacy of diversified routes into teaching and training roles includes parttime professional formation and alternative certification. In England, a series of fasttrack routes into vocational teaching has been based on an assumption that occupational expertise can replace the need for teachers to undergo a serious process of educational preparation. Yet the contested learning environments and differentiated roles reported here imply a need not for minimal preparation but for an enhanced professional formation, which can produce confident work-based practitioners with secure identities.

The concept of the subaltern educator recognises the difficult circumstances of former assessors, as well as, by implication, those of other educators marginalised outside traditional classroom settings, such as those in workshop settings (Esmond and Wood 2017). It complements notions of boundary-crossing that validate the work of classroom teachers, noting that vocational institutions and workplaces 'do different kinds of work, have different values and are structured by different kinds of knowledge and power' (Tanggaard 2007, p. 457). Whilst workplace learning is increasingly substituted for college-based education as part of a narrowing of curricula, it also has the potential to enhance educational practice by engagement between work-based practitioners and educators providing access to general knowledge, build authentic learning environments and communities in ways currently under exploration internationally (see for example NWO 2019). If the scope and detail of such development work lies beyond this paper and its limited data, the subaltern concept suggests approaches that can have value in wider areas of TVET, where the positions of educators are widely under review. 
Open Access This article is distributed under the terms of the Creative Commons Attribution 4.0 International License (http://creativecommons.org/licenses/by/4.0/), which permits unrestricted use, distribution, and reproduction in any medium, provided you give appropriate credit to the original author(s) and the source, provide a link to the Creative Commons license, and indicate if changes were made.

\section{References}

AELP (Association of Employment and Learning Providers) (2019). AELP Membership.https://www.aelp.org. uk/media/2345/membership-booklet-june18-final.pdf, accessed August 1 ${ }^{\text {st }} 2019$.

Armstrong, S. (2007). Factors impacting upon the performance of workplace assessors: A case study. International Journal of Training Research, 5(1), 1-20.

Avis, J. (1999). Shifting identity: New conditions and the transformation of practice - Teaching within postcompulsory education. Journal of Vocational Education and Training, 51(2), 245-264. https://doi. org/10.1080/13636829900200081.

Avis, J., \& Orr, K. (2014). The new professionalism: An exploration of vocational education and training teachers in England. In S. Billett, C. Harteis, \& H. Gruber (Eds.), International handbook of research in professional and practice-based learning (pp. 1099-1124). Dordrecht: Springer.

Billett, S. (2011). Vocational Education: Purposes, traditions and prospects. Dordrecht: Springer.

Billett, S. (2014). Mimesis: Learning through everyday activities and interactions at work. Human Resource Development Review, 13(4), 462-482.

Boreham, N. (2002). Work process knowledge, curriculum control and the work-based route to vocational qualifications. British Journal of Educational Studies, 50(2), 225-237.

Brockmann, M., Clarke, L., Méhaut, P., \& Winch, C. (2008). Competence-based vocational education and training (VET): The cases of England and France in a European perspective. Vocations and Learning, $1(3), 227-244$.

Chan, S. (2015). The contribution of observation to apprentices' Learning. Journal of Vocational Education and Training, 67(4), 442-459.

City \& Guilds (2019). 6317 TAQA Certification Volumes 1 October 2010-12 August 2019. David Wackett, personal communication.

Corbin, J. M., \& Strauss, A. (2015). Basics of qualitative research: Techniques and procedures for developing grounded theory (4th ed.). London: Sage.

Day, M. (1996). The role of the NVQ Assessor: National Vocational Qualifications and the 'D' units. Edinburgh: Campion Press.

DBIS. (Department for Business, Innovation and Skills). (2013). Future of apprenticeships in England: implementation plan (BIS/13/1175). London: Department for Business, Innovation and Skills.

Department for Education (2019) (DfE). Apprenticeship and levy statistics: January 2019. London: Department for Education. https://assets.publishing.service.gov.uk/government/uploads/system/uploads/attachment_ data/file/774452/Apprenticeship-and-levy-statistics-January-2019_FINALv2.pdf.

Ertl, H. \& P.F.E. Sloane. (2004). The German training system and the world of work: The transfer potential of the Lernfeldkonzept. Berufs- und Wirtschaftspädagogik. http://www.bwpat.de/7eu.

Esmond, B., \& Wood, H. (2017). More morphostasis than morphogenesis? The 'dual professionalism' of English Further Education workshop tutors. Journal of Vocational Education \& Training 69 (2):229-245. doi:https://doi.org/10.1080/13636820.2017.1309568.

ET 2020 Working Group on Vocational Education and Training. (2018). Teachers and trainers matter: How to support them in high-performance apprenticeships and work-based learning. Luxembourg: European Commission. http://www.schooleducationgateway.eu/en/pub/latest/news/et2020-workinggroup-onvocati.htm. Accessed 27 January 2019.

ETF (Education \& Training Foundation). (2014). Professional Standards for teachers and trainers in Education and training - England. London: ETF.

ETF (Education \& Training Foundation). (2016). New phase of the future apprenticeships programme. ETF. https:/www.et-foundation.co.uk/news/new-phase-future-apprenticeships-programme/. Accessed 20 August 2018.

Fjellström, M. (2017). Vocational learning in a Swedish post-secondary apprenticeship. Empirical Resesearch in Vocational Education and Training 9(5), doi:https://doi.org/10.1186/s40461-017-0051-6.

Frontier Economics. (2018). Further Education workforce data for England: Analysis of the 2016-2017 staff individualised record (SIR) data. London: Education and Training Foundation. 
Fuller, A., \& Unwin, L. (2003). Learning as apprentices in the contemporary UK workplace: Creating and managing expansive and restrictive participation. Journal of Education and Work, 16(4), 407-426.

Fuller, A., \& Unwin, L. (2004). Expansive learning environments: Integrating personal and organisational development. In H. Rainbird, A. Fuller, \& A. Munro (Eds.), Workplace learning in context (pp. 126-144). London: Routledge.

Fuller, A., \& Unwin, L. (2009). Change and continuity in apprenticeship: The resilience of a model of Learning. Journal of Education and Work, 22(5), 405-416.

Fuller, A., \& Unwin, L. (2017). Apprenticeship quality and social mobility. In Sutton Trust (Ed.), Better apprenticeships (pp. 9-36). London: Sutton Trust.

Gleeson, D., Davies, J., \& Wheeler, E. (2005). On the making and taking of professionalism in the further education workplace. British Journal of Sociology of Education, 26(4), 445-460.

Gleeson, D., \& James, D. (2007). The paradox of professionalism in English further Education: A TLC project perspective. Educational Review, 59(4), 451-467.

Gramsci, A. (1992). Prison notebooks. Volume I. J. Buttigieg. (Ed. \& trans.) New York: Columbia University Press.

Guha, R. (1988). The prose of counter-insurgency. In R. Guha \& G. C. Spivak (Eds.), Selected subaltern studies (pp. 45-86). Delhi: Oxford University Press.

Guile, D., \& Young, M. (2003). Transfer and transition in vocational education: Some theoretical considerations. In T. Tuomi-Gröhn \& Y. Engeström (Eds.), Between school and work: New perspectives on transfer and boundary-crossing (pp. 63-81). Amsterdam, Netherlands: Pergamon.

Hemkes, B., \& Schemme, D. (Eds.). (2013). Improving the quality of company-based learning: Practical guides for the implementation of the European quality strategy. Bonn: Bundesinstitut für Berufsbildung.

HM Government. (2015). English apprenticeships, Our 2020 Vision. BIS/15/604. London: Department for Business, Innovation and Skills.

HM Government. (2019). Apprenticeship funding rules for main providers. https://www.gov. uk/guidance/apprenticeship-funding-rules-for-training-providers/what-can-be-funded.

Hodgson, A. \& Spours, K. (2013). Why IfL should promote 'triple professionalism'. InTuition, 13. Summer. https://set.et-foundation.co.uk/publications/in-tuition/intuition-13-summer-2013/.

Hodgson, A., Spours, K., \& Smith, D. (2017). Future apprenticeships in England: The role of mediation in the new model. Journal of Education and Work, 30(6), 653-668.

James, D., \& Biesta, G. (2007). Improving Learning cultures in further Education. London: Routledge.

James, D., \& Diment, K. (2003). Going underground? Learning and assessment in an ambiguous space. Journal of Vocational Education and Training, 55(4), 407-422.

Jessup, G. (1991). Outcomes: NVQs and the emerging model of Education and training. London: Falmer.

Keep, E., \& James, S. (2011). Employer demand for apprenticeships. In Rethinking apprenticeships (pp. 5565). London: IPPR.

Kuczera, M., \& Field, S. (2018). Apprenticeship in England, United Kingdom. Paris: OECD.

Lifelong Learning, U. K. (2007). New overarching professional standards for teachers, tutors and trainers in the lifelong learning sector. London: Lifelong Learning UK.

Marsick, V. J., \& Watkins, K. E. (1990). Informal and incidental Learning in the workplace. London: Routledge.

Nägele, C. \& Neuenschwander, M.P. (2016). Apprentice-trainer relationship and workmgroup integration in the first months of an apprenticeship, Empirical Research in Vocational Education and Training, 8(4), doi: https://doi.org/10.1186/s40461-016-0030-3.

Newton, B., Miller, L., Williams, J., Buzzeo, J., \& Hinks, R. (2015). Process evaluation of apprenticeship trailblazers: Final report. London: Department for Business Industry and Skills.

NWO (Netherlands Organisation for Scientific Research). (2019). Human capital: Learning in Learning communities. Call for proposals. The Hague/Utrecht: Netherlands Organisation for Scientific Research.

OECD. (2013). TALIS 2013 Conceptual Framework. http://www.oecd.org/edu/school/TALIS\%20 Conceptual\%20Framework_FINAL.pdf. Accessed 14 ${ }^{\text {th }}$ April 2018.

Ofqual (Office of Qualifications and Examinations Regulation). (2017). Apprenticeship end-point assessments: Ofqual's approach to external quality assurance. Coventry: Ofqual.

Ofsted (Office for Standards in Education). (2015). Apprenticeships: Developing skills for future prosperity: How well do apprenticeships meet the needs of young people, their employers and the economy? Manchester: Ofsted.

Ofsted. (2017). Annual report of her Majesty's chief inspector of Education, Children's services and skills 2016/17. London: HMSO.

Ollin, R., \& Tucker, J. (2008). The NVQ Assessor, Verifier and Candidate Handbook: A Practical Guide to Units A1, A2 and V1, and STTTLSS Domain E (3rd ed.). London: Kogan Page. 
Ollin, R., \& Tucker, J. (2016). The vocational Assessor handbook: Including a guide to the QCF units for assessment and internal quality assurance (IQA) (6th ed.). London: Kogan Page.

Powell, A. \& O. Phelan. (2019). Apprenticeships Statistics: England. House of commons library briefing paper number 06113, $4^{\text {th }}$ January. https://researchbriefings.parliament.uk/ResearchBriefing/Summary/SN06113 \#fullreport.

QCA (Qualifications and Curriculum Authority). (2002). NVQ code of practice. London: QCA.

Richard, D. (2012). The Richard review of apprenticeships. London: School for Startups https://assets. publishing.service.gov.uk/government/uploads/system/uploads/attachment_data/file/34708/richardreview-full.pdf.

Robson, J., \& Bailey, B. (2009). 'Bowing from the heart': An investigation into discourses of professionalism and the work of caring for students in further education. British Educational Research Journal, 35(1), 99-117.

Ryan, P., \& Unwin, L. (2001). Apprenticeship in the British 'training market'. National Institute Economic Review, 178, 99-114.

Seale, C. (1999). The quality of qualitative research. London: Sage.

Silverman, D. (2014). Interpreting Qualitative Data. London: Sage.

Strauss, A. L. (1997). Mirrors and masks: The search for identity (2nd ed.). New Brunswick NJ: Transaction.

Tanggaard, L. (2007). Learning at trade vocational school and learning at work: Boundary crossing in apprentices' everyday life. Journal of Education and Work, 20(5), 453-466.

Winch, C. (2000). Education, work and social capital: Towards a new conception of vocational education. London: Routledge International Studies in the Philosophy of Education.

Wolf, A. (1995). Competence-based assessment. Buckingham: Open University Press.

Work Based Learning Workforce Survey. (2014). 2012/13 Survey. London: AELP-ETF.

Publisher's Note Springer Nature remains neutral with regard to jurisdictional claims in published maps and institutional affiliations.

Bill Esmond is Associate Professor Learning and Employment at the University of Derby, UK, with particular interests in comparative VET, post-secondary systems and the work of vocational educators. His published work spans workplace learning, apprenticeship and transition. 